\title{
CINÉTICA DA DIGESTÃo RUMINAL DA CASCA DE CAFÉ (Coffea arabica, L.) EM VACAS DA RAÇA HOLANDESA ${ }^{1}$
}

\author{
Kinetics of the ruminal digestion of coffee hulls (Coffea arabica, L.) in holstein cows \\ Edésio Ribeiro Filho ${ }^{2}$, Paulo César de Aguiar Paiva ${ }^{3}$, Euclides Reuter de Oliveira ${ }^{4}$, \\ Adauto Ferreira Barcelos ${ }^{5}$, Ana Luisa Aguiar de Castro ${ }^{6}$, Juliana Santos ${ }^{6}$
}

\begin{abstract}
RESUMO
Com o objetivo de avaliar a cinética da digestão ruminal pela técnica da degradabilidade in situ, da matéria seca (MS), proteína bruta (PB) e fibra em detergente neutro (FDN) de rações isoenergéticas e isoprotéicas, com $16 \%$ de PB e diferentes níveis $(0,10,20,30$ e 40\%) de substituição do milho desintegrado com palha e sabugo (MDPS) por casca de café, conduziu-se um experimento no Departamento de Zootecnia da Universidade Federal de Lavras - UFLA, Lavras - Minas Gerais, Brasil, com 3 vacas da raça holandesa, com cânulas ruminais, nas quais foram incubadas amostras de volumoso, casca de café, MDPS e rações experimentais por 0, 6, 12, 24, 48, 72 e 96 horas. Os dados de degradabilidade foram ajustados para uma regressão não-linear pelo método de Gauss-Newton. Pelos resultados obtidos, pôde-se avaliar que, com o aumento dos níveis de casca de café, a degradabilidade efetiva da MS das rações apresentou-se semelhante à da ração sem esse resíduo, observandose também uma tendência de aumento da degradabilidade efetiva da PB. Porém, com a FDN, o efeito foi de redução da degradabilidade efetiva. Conclui-se que a substituição do MDPS pela casca de café, até o nível de $40 \%$, não afetou a degradabilidade efetiva da MS e PB dos concentrados. Entretanto, reduziu a degradabilidade efetiva da FDN.
\end{abstract}

Termos para indexação: Casca de café, degradabilidade ruminal, suplemento.

\section{ABSTRACT}

In order to evaluate the kinetics of ruminal digestion by means of the in situ incubation tectonics of the dry matter $(\mathrm{DM})$, crude protein $(\mathrm{CP})$ and neuter detergent fiber (NDF) of isoenergetic and isoprotein rations with $16 \%$ of crude protein with different levels $(0,10,20,30$ and $40 \%)$ of replacement of ground corn with straw and cob (GCSC) for coffee hull, an experiment was conducted at the Department of Animal Science of the Universidade Federal de Lavras - UFLA - Lavras - MG, Brazil, with three non-lactating cows of the holstein breed, fitted with ruminal cannulas into which samples of forage, coffee hull, CGSC and experimental rations for $0,6,12,24,48,72$ and 96 hours were incubated. The data obtained about the degradability were fit for a non-linear regression by Gauss-Newton's method. The data obtained allowed to evaluate that with increasing levels of coffee hull, the effective degradability of the dry matter of the rations proved similar to that of the ration without that residue, a trend of increased effectively degraded protein being also observed. But with neuter detergent fiber the effect was the reduction of effective degradability. Based upon this experiment, it follows that the replacement of GCSC for coffee hull up to the level of $40 \%$ did not affect the effective degradability of both the dry matter and crude protein of concentrates. Nevertheless, it reduced the effective degradability of neuter detergent fiber.

Index terms: Coffee hulls, ruminal digestibility, supplement.

(Recebido para publicação em 21 de agosto de 2002 e aprovado em 3 de dezembro de 2002)

\section{INTRODUÇÃO}

A degradabilidade in situ é uma técnica que permite determinar simultaneamente a quantidade de amostra do alimento que é digerida e a taxa pela qual essa digestão se realiza (RUIZ e RUIZ, 1990). Essa téc- nica tem sido objeto de vários trabalhos de pesquisa para descrever características de degradação de frações da parede celular e proteína dos alimentos, estimada pela incubação de alimentos em sacos de náilon no rúmen, (VALADARES FILHO et al., 1990; AROEIRA et al., 1993; TEIXEIRA, 1995).

\footnotetext{
1. Pesquisa financiada pelo Departamento de Zootecnia - Universidade Federal de Lavras/UFLA - Caixa Postal 37 - 37200-000 - Lavras, MG

2. Agrônomo - MS - Banco do Nordeste - Campina Grande, PB.

3. Professor do Departamento de Zootecnia - UFLA, bolsista do CNPq.

4. Professor, Pesquisador CAPES - DPA/EV/UFGRua 97, n³96 - Setor Sul - Goiânia, GO - reuter@vet.ufg.br.

5. Pesquisador da EPAMIG-CTSM - adauto.barcelos@epamig.ufla.br.

6. Estudante do Curso de Mestrado - Departamento de Zootecnia/UFLA
} 
A dieta é o fator de maior importância na determinação da quantidade e tipo de microorganismos ruminais e, conseqüentemente, da taxa e extensão de de-gradação do alimento (NOCEK, 1988). Alimentos com concentrações variadas de proteína e energia utilizados nos ensaios de degradabilidade in situ têm mostrado efeitos variados sobre os resultados. A degradação protéica no rúmen depende da fonte de proteína, do processamento físico e químico dessa fonte protéica e do "turnover" do rúmen (LUCCI, 1997). Nocek (1988) recomenda que as dietas basais, que serão degradadas in situ, sejam preferencialmente as mesmas a serem estudadas, observando-se a mesma relação volumoso:concentrado.

Pesquisas sobre a degradabilidade ruminal dos nutrientes da casca de café ainda são limitadas (TEIXEIRA, 1995). Furusho (1995) estudou a degradabilidade efetiva da matéria seca (MS), fibra em detergente neutro (FDN) e proteína bruta (PB) da casca de café tratada e não tratada com uréia em vacas Holandesas e verificou pequeno efeito do tratamento químico sobre a degradabilidade efetiva da MS e da FDN e aumento na degradabilidade efetiva da PB. Para a casca de café pura, observaram-se $25,1 \%$ de degradabilidade efetiva da MS; 38,8\% de degradabilidade efetiva da PB e 9,23\% de degradabilidade efetiva da FDN. Resultados semelhantes foram encontrados por Teixeira et al. (1995), que obtiveram $29,8 \%, 40,0 \%$ e $34,0 \%$ para degradabilidade efetiva da MS, PB e FDN, respectivamente, tendo atribuído os valores relativamente baixos às prováveis interferências do alto teor de lignina e taninos da casca de café.

Segundo Bressani et al. (1972), a cafeína, taninos e os polifenóis (ácido clorogênico e caféico) são fatores que interferem na utilização dos nutrientes da polpa de café, tendo Vargas et al. (1977) atribuído às altas concentrações de cafeína e tanino a responsabilidade pela baixa eficiência de utilização de proteína na polpa de café.

Teixeira et al. (1997) utilizaram vacas holandesas para estudar, pela técnica in situ, a degradabilidade ruminal da MS, PB e FDN da casca de café em duas seqüências distintas de tempo e incubação, e concluíram que a degradabilidade efetiva da MS, PB e FDN não tiveram efeito significativo dos tratamentos e que os resultados para a degradabilidade efetiva da MS, PB e FDN foram $53,49 \% ; 63,79 \%$ e $66,62 \%$, respectivamente.

Considerando a importância da casca de café na alimentação de bovinos devido a sua alta disponibilidade na região e propondo o seu melhor aproveitamento técnico-econômico, foi conduzido este experimento com o objetivo de determinar a cinética da digestão ruminal da MS, PB e FDN de rações, com base na casca de café, em substituição ao milho desintegrado com palha e sabugo (MDPS), em vacas da raça holandesa.

\section{MATERIAL E MÉTODOS}

O experimento foi conduzido na Universidade Federal de Lavras - UFLA, Lavras - MG, no Setor de Bovinocultura de Leite do Departamento de Zootecnia. Teve duração de 30 dias, de novembro a dezembro de 1997, consistindo de um período préexperimental de 15 dias para adaptação dos animais às dietas.

As dietas experimentais consistiram de 5 rações com níveis $(0,10,20,30$ e $40 \%)$ de substituição do MDPS por casca de café (Tabela 1). Além das dietas experimentais, foram incubadas amostras de capimelefante, casca de café e MDPS.

As amostras das rações e casca de café foram moídas em moinho de martelo com peneira de 2 $\mathrm{mm}$, ao passo que o capim-elefante e o milho desintegrado com palha e sabugo foram moídos na peneira de $5 \mathrm{~mm}$.

Foram utilizadas três vacas holandesas, nãolactantes, providas de fístulas ruminais permanentes, com peso vivo médio de aproximadamente $400 \mathrm{~kg}$, devidamente vacinadas, vermifugadas e livres de ectoparasitas.

O período experimental durou 30 dias, inclusive 15 dias para adaptação do ecossistema ruminal à dieta contendo uma média representativa dos tratamentos experimentais.

Cada animal recebeu $3,0 \mathrm{~kg}$ da ração concentrada/dia em duas porções iguais, de manhã e à tarde. Além do concentrado, as vacas receberam, ad libitum, capim-elefante picado no cocho, de modo a obter relação de consumo concentrado:volumoso próximo de 40:60. 
TABELA 1 - Composição das rações experimentais em percentual na matéria seca (MS).

\begin{tabular}{lccccc}
\hline \multirow{2}{*}{ Ingredientes } & \multicolumn{5}{c}{ Tratamentos } \\
\cline { 2 - 6 } & $\mathbf{0 \%}$ & $\mathbf{1 0 \%}$ & $\mathbf{2 0 \%}$ & $\mathbf{3 0 \%}$ & $\mathbf{4 0 \%}$ \\
\hline Casca de café & 0,00 & 10,00 & 20,00 & 30,00 & 40,00 \\
MDPS $^{1}$ & 40,00 & 30,00 & 20,00 & 10,00 & 0,00 \\
Milho moído & 20,00 & 20,00 & 20,00 & 20,00 & 20,00 \\
Farelo de trigo & 16,73 & 17,47 & 18,20 & 18,93 & 19,67 \\
Farelo de soja & 21,27 & 20,53 & 19,80 & 19,07 & 18,33 \\
Calcário calcítico & 1,00 & 1,00 & 1,00 & 1,00 & 1,00 \\
Mistura mineral $^{2}$ & 1,00 & 1,00 & 1,00 & 1,00 & 1,00 \\
\hline
\end{tabular}

${ }^{1}$ MDPS = Milho desintegrado com palha e sabugo

${ }^{2}$ Fósforo, $130 \mathrm{~g} / \mathrm{kg}$; cálcio, $190 \mathrm{~g} / \mathrm{kg}$; magnésio, $18 \mathrm{~g} / \mathrm{kg}$; enxofre, 36g/kg; zinco, $6.000 \mathrm{mg} / \mathrm{kg}$; cobre, 1.300 $\mathrm{mg} / \mathrm{kg}$; manganês, $2.000 \mathrm{mg} / \mathrm{kg}$; ferro, $5.500 \mathrm{mg} / \mathrm{kg}$; cobalto, $200 \mathrm{mg} / \mathrm{kg}$; iodo, $300 \mathrm{mg} / \mathrm{kg}$; selênio, $20 \mathrm{mg} / \mathrm{kg}$; flúor, $1.300 \mathrm{mg} / \mathrm{kg}$.

Para a determinação da degradabilidade in situ da MS, PB e FDN, foi adotada a técnica proposta por Mehrez e Orskov (1977), com algumas recomendações propostas por Nocek (1988).

Amostras de 3,5 g de cada ração experimental, casca de café, capim-elefante e MDPS foram colocadas em sacos de poliéster medindo 9,0 x 11,0 cm, com porosidade de $55 \mu$. Em seguida, os sacos foram fechados a quente em máquina seladora. Seguiram-se as sugestões de Nocek (1988), mantendo-se a relação de 15-20 $\mathrm{mg}$ de alimento/ $\mathrm{cm}^{2}$ do saco.

Depois de pesados, os sacos foram colocados em uma sacola de fíló $(15,00$ x 30,00 cm) juntamente com um pequeno peso de chumbo de aproximadamente $100 \mathrm{~g}$. A sacola de filó teve sua abertura amarrada com um fio de náilon e esse foi preso à cânula. A sacola foi depositada na porção ventral do rúmen por $0,6,12,24,48,72$ e 96 horas. Esse procedimento foi repetido para cada uma das 3 vacas fistuladas.

Foram confeccionados 3 sacos por alimento/tempo/animal, perfazendo um total de 504 sacos.

Após o período de incubação, os sacos de náilon, contendo resíduos das amostras, foram retirados e imediatamente lavados em máquina apropriada, com água corrente, durante 10 minutos. Em seguida, foram colocados em estufa de ventilação forçada a uma temperatura de $60^{\circ} \mathrm{C}$ durante 48 horas e, depois, resfriados em dessecador para as respectivas pesagens.

Os sacos referentes ao tempo zero (utilizados para determinar a fração solúvel) foram introduzidos na massa ruminal e retirados após 10 segundos de submersão, recebendo, depois, o mesmo tratamento destinado aos demais tempos.

O material remanescente nos sacos foi analisado quanto aos teores de matéria seca a $105^{\circ} \mathrm{C}$, segundo a AOAC (1970), proteína bruta (PB), pela dosagem do nitrogênio total, conforme método de Kjeldahl (AOAC, 1970) e fibra em detergente neutro (FDN) segundo Soest (1967). Para os resíduos representativos de amostras à base de milho, foi adicionada uma solução enzimática de $\alpha$-amilase para remover o amido nas soluções quentes de detergente neutro.

Os dados obtidos sobre o desaparecimento da matéria seca, proteína bruta e fibra em detergente neutro, nos diferentes tempos de incubação, foram ajustados para uma regressão não-linear, pelo método de Gauss-Newton (NETER et al., 1985), de acordo com a equação proposta por Orskov e McDonald (1979), considerando-se a taxa de passagem da digesta para o duodeno de $5 \% / \mathrm{h}(\mathrm{k}=0,05)$, em que: 
"a" = fração solúvel $(\%)$, indicando solubilidade;

"b" = fração insolúvel potencialmente degradável (\%);

"c" =taxa de degradação (fracional/hora);

$" k "=$ taxa de passagem ruminal do alimento $(\% / \mathrm{h})$.

Degradabilidade potencial $(D P)=a+b\left(1-e^{-c t}\right)$ representando a degradabilidade máxima alcançada pelo alimento por $96 \mathrm{~h}$;

Degradabilidade efetiva $(\mathrm{DE})=\mathrm{a}+(\mathrm{b} * \mathrm{c}) /(\mathrm{c}+\mathrm{k})$ levando em conta o percurso normal do alimento pelo trato gastrointestinal,

Os dados obtidos foram analisados pelo pacote computacional SAEG, descrito por Euclydes (1983).

\section{RESULTADOS E DISCUSSÃO}

Os teores médios de matéria seca (MS) e a composição bromatológica do volumoso, ingredien- tes e concentrados encontram-se na Tabela 2 e são semelhantes a dados da literatura (CAIELI, 1984; LEITÃO, 1995; FURUSHO, 1995; BARCELOS et al., 1996).

Os valores das frações solúvel (a) e insolúvel potencialmente degradável (b), taxa de degradação (c), degradabilidade potencial (DP), degradabilidade efetiva (DE) e fração não degradada (FND) da MS das rações experimentais, volumoso, MDPS e casca de café estão na Tabela 3.

A degradabilidade inicial da MS dos concentrados mostra que o desaparecimento da fração solúvel (a) da ração sem casca foi semelhante à fração solúvel (a) das demais misturas de concentrados, à medida que se elevou o teor de casca de café, em substituição ao MDPS. Isso pode ser devido à semelhança da fração solúvel (a), no tempo zero, da degradabilidade apresentada pelo MDPS e casca de café (Figura 1).

TABELA 2 - Composição bromatológica do volumoso, ingredientes e concentrados.

\begin{tabular}{|c|c|c|c|c|}
\hline Componentes & MS (\%) & $\mathbf{P B}^{1}(\%)$ & $\operatorname{FDN}^{1}(\%)$ & $* \operatorname{NDT}(\%)$ \\
\hline \multicolumn{5}{|c|}{ Volumoso } \\
\hline Capim elefante & 46,23 & 3,86 & 86,21 & 43,59 \\
\hline \multicolumn{5}{|c|}{ Ingredientes } \\
\hline Casca de café & 90,03 & 8,52 & 70,72 & 48,00 \\
\hline MDPS & 90,74 & 6,21 & 42,86 & 60,00 \\
\hline Milho moído & 87,85 & 6,70 & 16,85 & 80,00 \\
\hline Farelo de trigo & 90,29 & 15,84 & 49,02 & 67,00 \\
\hline Farelo de soja & 89,25 & 43,84 & 18,02 & 71,00 \\
\hline \multicolumn{5}{|c|}{ Rações } \\
\hline $0 \%$ de casca de café & 89,91 & 15,80 & 32,55 & 66,31 \\
\hline $10 \%$ de casca de café & 89,99 & 15,82 & 35,56 & 65,08 \\
\hline $20 \%$ de casca de café & 89,95 & 15,85 & 38,58 & 63,84 \\
\hline $30 \%$ de casca de café & 90,42 & 15,88 & 41,59 & 62,62 \\
\hline $40 \%$ de casca de café & 91,36 & 15,90 & 44,60 & 61,39 \\
\hline
\end{tabular}

\footnotetext{
1 - base de Matéria Seca (MS)

* O NDT foi calculado segundo dados coletados dos ingredientes na literatura
}

Ciênc. agrotec., Lavras, v. 28, n. 3, p. 627-636, maio/jun., 2004 
TABELA 3 - Valores das frações solúvel (a) e insolúvel potencialmente degradável (b), taxa de degradação (c), degradabilidade potencial (DP), degradabilidade efetiva (DE) e fração não degradada (FND) da matéria seca das rações experimentais, volumoso, MDPS e casca de café.

\begin{tabular}{ccccccc}
\hline \multirow{2}{*}{ Alimentos } & $\mathbf{~}$ & $\mathbf{b}$ & $\mathbf{c}$ & $\mathbf{D P}$ & $\mathbf{D E}$ & FND \\
\cline { 2 - 7 } & $\mathbf{\%}$ & $\mathbf{\%}$ & $\mathbf{\%} / \mathbf{h}$ & $\mathbf{\%}$ & $\mathbf{\%}$ & $\mathbf{\%}$ \\
\hline Rações & & & & & & \\
$0 \%$ de casca de café & 35,18 & 56,68 & 0,0561 & 91,86 & 65,16 & 8,14 \\
$10 \%$ de casca de café & 36,63 & 53,88 & 0,0466 & 90,51 & 62,62 & 9,49 \\
$20 \%$ de casca de café & 38,00 & 48,42 & 0,0538 & 86,42 & 63,10 & 13,58 \\
$30 \%$ de casca de café & 36,47 & 47,33 & 0,0588 & 83,80 & 62,05 & 16,20 \\
$40 \%$ de casca de café & 37,08 & 42,44 & 0,0543 & 79,52 & 59,17 & 20,48 \\
$\quad$ Volumoso & & & & & & \\
Capim elefante & 21,91 & 38,06 & 0,0199 & 59,97 & 32,75 & 40,03 \\
$\quad$ Ingredientes & & & & & & \\
Casca de café & 30,23 & 21,20 & 0,0356 & 51,43 & 39,05 & 48,57 \\
MDPS & 31,55 & 64,21 & 0,0465 & 95,76 & 62,49 & 4,24 \\
\hline
\end{tabular}

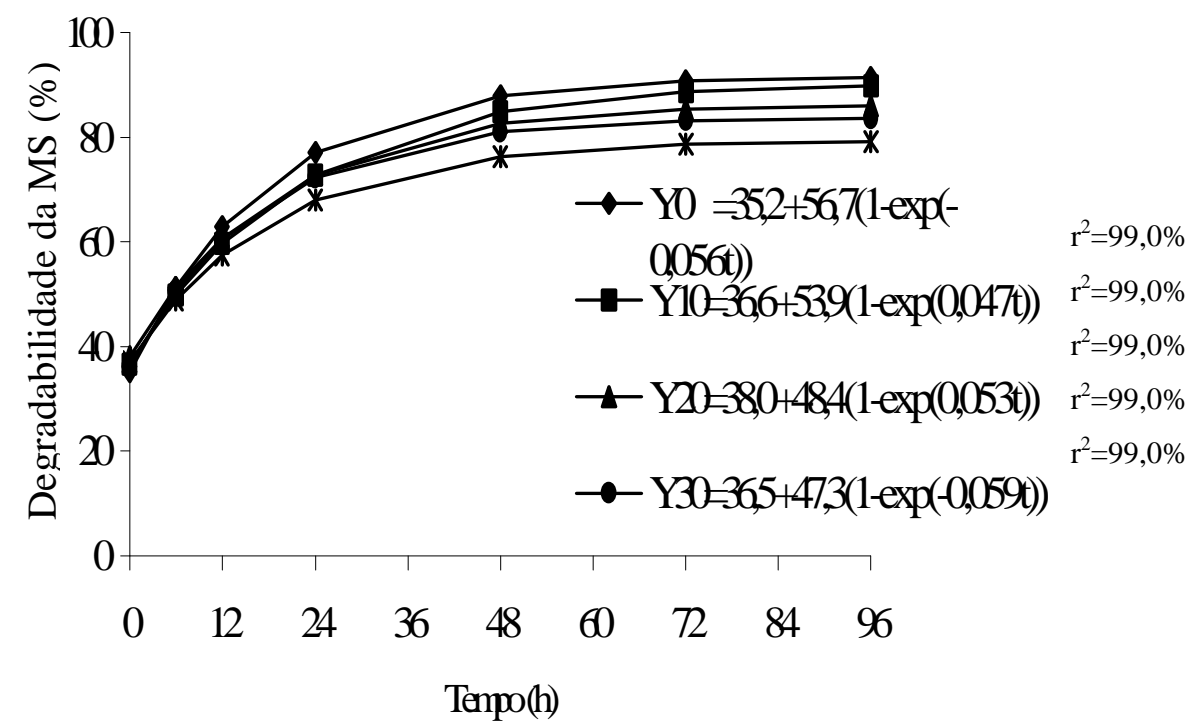

FIGURA 1 - Degradabilidade potencial (DP) estimada para a matéria seca, das rações experimentais, nos diferentes tempos de incubação. 
Com o aumento dos níveis de casca de café, observou-se que a fração insolúvel potencialmente degradável (b) da MS das rações foi decrescendo, provavelmente porque a fração insolúvel potencialmente degradável (b) da MS da casca de café mostrou-se menos disponível à fermentação do que o MDPS.

Verificou-se um decréscimo de degradabilidade efetiva (DE) da MS com o aumento da casca de café nos concentrados

Observou-se, também, que houve aumento da fração não degradada da MS dos concentrados quando os níveis de casca foram elevados, provavelmente porque o percentual de $\mathrm{MS}$ da casca que escapa à degradação foi superior ao do MDPS.

As curvas de degradabilidade efetiva (DE) da MS demonstram a redução da degradabilidade efetiva da MS com o aumento da casca de café nos concentrados, observando-se que as bactérias ruminais tiveram melhor atuação entre os períodos de 12 a 24 horas de incubação.
Os valores de a, b, c, DP, DE e FND da PB das rações experimentais, volumoso, MDPS e casca de café estão na Tabela 4.

A degradabilidade inicial da PB das rações mostra que a fração solúvel (a) aumentou com os níveis de casca de café nas rações, atribuindo-se isso à maior fração de proteína solúvel encontrada na casca que no MDPS.

Com a elevação dos níveis de casca, em substituição ao MDPS, verificou-se que a fração insolúvel potencialmente degradável (b) dos concentrados foi decrescendo. Isso se verificou porque, provavelmente, a fração insolúvel potencialmente degradável (b) da casca apresenta menos disponibilidade fermentativa que o MDPS.

Observaram-se valores crescentes relativamente altos de degradabilidade efetiva (DE) da proteína bruta dos concentrados, sugerindo que o processamento físico de moagem aplicado à casca de café tenha proporcionado uma atuação mais eficaz das bactérias ruminais sobre as partículas desse resíduo, observada, sobretudo, entre o período de 12 a 24 horas de incubação (Figura 2).

TABELA 4 - Valores das frações solúvel (a) e insolúvel potencialmente degradável (b), taxa de degradação (c), degradabilidade potencial (DP), degradabilidade efetiva (DE) e fração não degradada (FND) da proteína bruta (PB) das rações experimentais, volumoso, MDPS e casca de café.

\begin{tabular}{ccccccc}
\hline \multirow{2}{*}{ Alimentos } & $\mathbf{~}$ & $\mathbf{b}$ & $\mathbf{c}$ & $\mathbf{D P}$ & $\mathbf{D E}$ & FND \\
\cline { 2 - 7 } & $\mathbf{\%}$ & $\mathbf{\%}$ & $\mathbf{\%} / \mathbf{h}$ & $\mathbf{\%}$ & $\mathbf{\%}$ & $\mathbf{\%}$ \\
\hline Rações & & & & & & \\
$0 \%$ de casca de café & 29,37 & 68,96 & 0,0570 & 98,33 & 66,11 & 1,67 \\
$10 \%$ de casca de café & 33,13 & 65,01 & 0,0480 & 98,14 & 64,97 & 1,86 \\
$20 \%$ de casca de café & 36,15 & 59,99 & 0,0630 & 96,14 & 69,60 & 3,86 \\
$30 \%$ de casca de café & 31,76 & 64,55 & 0,0600 & 96,31 & 66,97 & 3,69 \\
$40 \%$ de casca de café & 37,31 & 57,37 & 0,0680 & 94,68 & 70,37 & 5,32 \\
$\quad$ Volumoso & & & & & & \\
Capim-elefante & 41,18 & 32,66 & 0,0150 & 73,84 & 48,72 & 26,16 \\
$\quad$ Ingredientes & & & & & & \\
Casca de café & 55,68 & 25,10 & 0,0350 & 80,78 & 66,02 & 19,22 \\
MDPS & 30,20 & 65,70 & 0,0500 & 95,90 & 63,05 & 4,10 \\
\hline
\end{tabular}

Ciênc. agrotec., Lavras, v. 28, n. 3, p. 627-636, maio/jun., 2004 


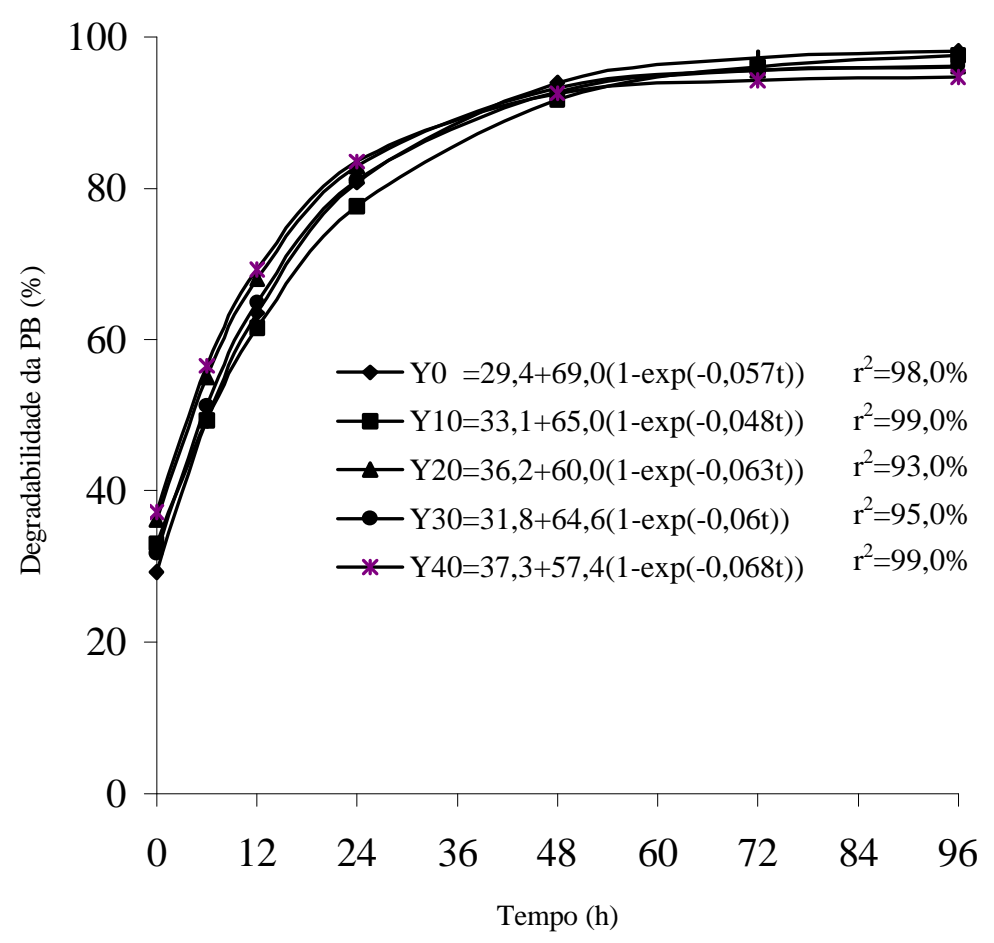

FIGURA 2 - Degradabilidade potencial (DP) estimada para a proteína bruta das rações experimentais, nos diferentes tempos de incubação.

Verificou-se baixo percentual de fração não degradada da proteína bruta dos concentrados, porém, esses níveis foram aumentando com o aumento dos teores de casca de café nos concentrados (Figura 2).

Os valores de a e b, c, DP, DE e FND da FDN das rações experimentais, volumoso, MDPS e casca de café estão na Tabela 5.

Os valores da fração insolúvel potencialmente degradável (b) da fibra em detergente neutro dos concentrados decresceram com a elevação dos níveis de casca, possivelmente pelo fato de a casca apresentar elevado percentual de FDN não disponível à fermentação muito superior ao MDPS.

A redução da taxa de degradação (c) da fração insolúvel potencialmente degradável (b) da FDN dos concentrados, com o aumento dos níveis de casca de café nas rações, é atribuída à baixa disponibilidade da ação fermentativa dessa fração insolúvel, em detri- mento da fração remanescente da parede celular que escapou da degradação ruminal, aumentando, conseqüentemente, a fração não degradada.

As taxas de degradação (c) da FDN das rações, inferiores à taxa de saída do rúmen por hora, coincidem com dados do "Sistema de Carboidratos e Proteína Líquidos para Avaliação de Dietas de Bovinos (The Cornell Net Carbohydrate and Protein System for Evaluating Cattle Diets-CNCPS), citado por Rossi Júnior (1994), segundo o qual a FDN disponível para degradação ruminal apresenta taxa de degradação baixa, com valores próximos aos da taxa de passagem.

A degradabilidade efetiva (DE) da fibra em detergente neutro dos concentrados diminuiu com a elevação dos níveis de casca de café em substituição ao MDPS (Tabela 5), observando-se atuação mais efetiva das bactérias ruminais no período de 12 a 24 horas de incubação (Figura 3). 
TABELA 5 - Valores das frações solúvel (a) e insolúvel potencialmente degradável (b), taxa de degradação (c), degradabilidade potencial (DP), degradabilidade efetiva (DE) e fração não degradada (FND) da fibra em detergente neutro (FDN) das rações experimentais, volumoso, MDPS e casca de café

\begin{tabular}{|c|c|c|c|c|c|c|}
\hline \multirow{2}{*}{ Alimentos } & $\mathbf{a}$ & b & c & DP & DE & ND \\
\hline & $\%$ & $\%$ & $\% / h$ & $\%$ & $\%$ & $\%$ \\
\hline \multicolumn{7}{|l|}{ Rações } \\
\hline $0 \%$ de casca de café & 15,93 & 64,59 & 0,046 & 80,52 & 46,88 & 19,48 \\
\hline $10 \%$ de casca de café & 12,76 & 63,58 & 0,037 & 76,34 & 39,80 & 23,66 \\
\hline $20 \%$ de casca de café & 26,26 & 49,00 & 0,030 & 75,26 & 44,64 & 24,74 \\
\hline $30 \%$ de casca de café & 23,15 & 45,98 & 0,031 & 69,13 & 40,75 & 30,87 \\
\hline $40 \%$ de casca de café & 19,64 & 44,50 & 0,033 & 64,14 & 37,33 & 35,86 \\
\hline \multicolumn{7}{|l|}{ Volumoso } \\
\hline Capim elefante & 20,55 & 40,10 & 0,019 & 60,65 & 31,59 & 39,35 \\
\hline \multicolumn{7}{|l|}{ Ingredientes } \\
\hline Casca de café & 18,32 & 22,19 & 0,034 & 40,51 & 27,30 & 59,49 \\
\hline MDPS & 24,76 & 67,00 & 0,033 & 91,76 & 51,40 & 8,24 \\
\hline
\end{tabular}

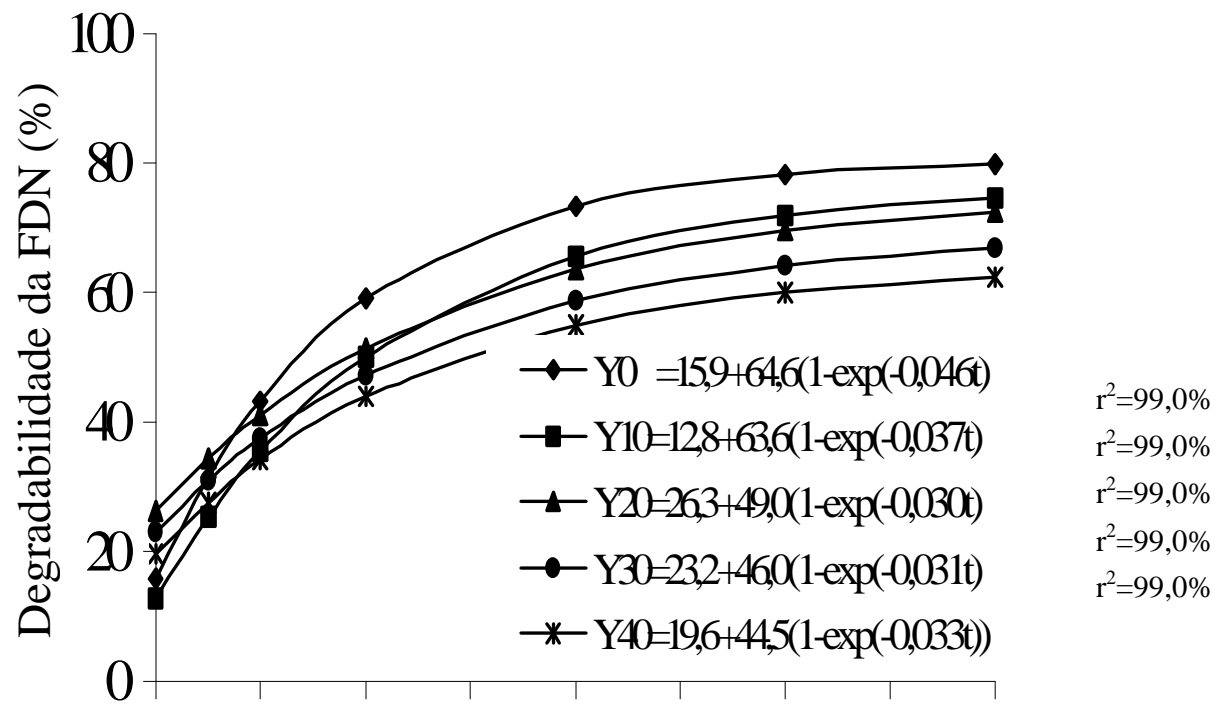

\section{$\begin{array}{lllllllll}0 & 12 & 24 & 36 & 48 & 60 & 72 & 84 & 96\end{array}$ Tempo(h)}

FIGURA 3 - Degradabilidade potencial (DP) estimada para a fibra em detergente neutro, das rações experimentais, nos diferentes tempos de incubação.

Ciênc. agrotec., Lavras, v. 28, n. 3, p. 627-636, maio/jun., 2004 


\section{CONCLUSÕES}

A casca de café, em substituição ao MDPS, pode ser utilizada em até $40 \%$.

Novos trabalhos devem ser pesquisados.

\section{REFERÊNCIAS BIBLIOGRÁFICAS}

AROEIRA, L. J. M.; SILVEIRA, M. I.; LIZIEIRE, R. S. Degradabilidade no rúmen e taxa de passagem da cana de açúcar mais uréia, do farelo de algodão e do farelo de arroz em novilhos mestiços Europeu x Zebu. Revista da Sociedade Brasileira de Zootecnia, Viçosa, v. 22, n. 4, p. 552-564, 1993.

ASSOCIATION OF OFFICIAL AGRICULTURE CHEMISTS. Official method of analysis. 11. ed. Washington, 1970. $1015 \mathrm{p}$.

BARCELOS, A. F.; ANDRADE, I. F. de; TIESENHAUSEN, I. M. E. V. von; FERREIRA, J. J.; SETTE, R. de S.; AMARAL, R.; PAIVA, P. C. A. Aproveitamento da casca de café na alimentação de bezerros em crescimento. In: REUNIÃO ANUAL DA SOCIEDADE BRASILEIRA DE ZOOTECNIA, 33., 1996, Fortaleza. Anais... Fortaleza: SBZ, 1996. p. 46.

BRESSANI, R.; ESTRADA, E.; JARQUIN, R. Pulpa y pergamino de café: I. composición química contenido de aminoácidos de la proteína de la pulpa. Turrialba, San José, n. 3, p. 299-304, jul. 1972.

CAIELLI, E. L. Uso da palha de café na alimentação de ruminantes. Informe Agropecuário, Belo Horizonte, v. 10, n. 119 , p. 36-38, nov. 1984.

EUCLYDES, R. F. Manual de utilização do programa SAEG - Sistema para Análises Estatísticas e Genéticas. Viçosa: UFV, 1983. 59 p.

FURUSHO, I. F. Efeito da utilização da casca de café, " in natura" e tratada com uréia, sobre o desempenho e características de carcaça de cordeiros terminados em confinamento. 1995. 72 f. Dissertação (Mestrado em Zootecnia) - Universidade Federal de Lavras, Lavras, 1995.

LEITÃO, R. A. Valor nutritivo da casca de café (Coffea arabica, l.), tratada com hidróxido de sódio e/ou uréia suplementada com feno de alfafa (Medicago sativa, L.). 1995. 60 f. Dissertação (Mestrado em Zootecnia) - Universidade Federal de Lavras, Lavras, 1995.
LUCCI, C. S. Nutrição e manejo de bovinos leiteiros. São Paulo: MANOLE, 1997. 169 p.

MEHREZ, A. Z.; ORSKOV, E. R. Study of the artificial fibre bag technique of determining the digestibility of feeds in the rumen. Journal of Agricultural Science, Cambridge, v. 88, p. 645-650, 1977.

NETER, J.; WASSWERMAN, W.; KUTNER, M. H. Liner statistical models: regression, analyses of variance and experimental designes. 2. ed. Washington: R. D. Irwin, 1985. $1125 \mathrm{p}$.

NOCEK, J. E. In situ and other methods to estimate ruminal protein and energy digestibility: a review. Journal of Dairy Science, Champaign, v. 71, n. 8, p. 2051-2069, 1988.

ORSKOV, E. R.; MCDONALD, I. The estimation of protein degradability in the rumen from incubation measurements weighted according to rate of passage. Journal of Agricultural Science, Cambridge, v. 92, p. 499-503, 1979.

ROSSI JÚNIOR, P. Degradabilidade ruminal dos componentes da fração nitrogenada e de carboidratos de silagem de milho, farelo de soja e sorgo grão, em bovinos da raça Nelore. 1994. 100 f. Dissertação (Mestrado em Ciência Animal e Pastagem) - Escola Superior de Agricultura de Luiz de Queiroz, Piracicaba, 1994.

RUIZ, M. E.; RUIZ, A. Nutricion de rumiantes: guia metodologica de investigación. San José: [s.n.], 1990. $340 \mathrm{p}$.

SOEST, P. J. van. Development of a comprehensive system of feed analysis and its application to forages. Journal of Animal Science, Champaign, v. 26, n. 1, p. 119-128, Jan. 1967.

TEIXEIRA, J. C. Café. In: SIMPÓSIO SOBRE NUTRIÇÃO DE BOVINOS, 6., 1995, Piracicaba. Anais... Piracicaba: FEALQ, 1995. p. 123-151.

TEIXEIRA, J. C.; BARBOSA, A. C.; PAIVA, A. C.; PEREZ, J. R. O.; OLIVEIRA, A. I. G. de; FRAGA, A. C. Avaliação da sequiência e tempo de incubação de sacos de náilon no rúmen afetando a estimativa da degradabilidade ruminal da matéria seca, proteína bruta e fibra em detergente neutro. In: REUNIÃO ANUAL DA SOCIEDADE BRASILEIRA DE ZOOTECNIA, 34., 1997, Juiz de Fora. Anais... Juiz de Fora: SBZ, 1997. p. 21-33. 
TEIXEIRA, J. C.; DELGADO, E. F.; CORREA, E. M. Degradabilidade ruminal da matéria seca e proteína bruta do grão de soja, cru ou tostado, em diferentes formas físicas, em vacas da raça Holandesa. Ciência e Prática, Lavras, v. 19, n. 1, p. 105-110, jan./mar. 1995.

VALADARES FILHO, S. C.; SILVA, J. F. C. da; LEÃO, M. I. Degradabilidade in situ da matéria seca e proteína bruta de vários alimentos em vacas em lacta- ção. Revista da Sociedade Brasileira de Zootecnia, Viçosa, v. 19, n. 6, p. 512-522, 1990.

VARGAS, E.; CABEZAS, M. T.; BRESSANI, R. Pulpa de café en la alimentación de rumiantes: II. absorción y retención de nitrogeno em novillos alimentados com concentrado elaborado com pulpa de café deshidratada. Agronomia Costarricense, San José, v. 1, n. 2, p. 101106, 1977. 